\title{
Improving Science Attitude and Creative Thinking through Science Education Project: A Design, Implementation and Assessment
}

\author{
Nilay Şener ${ }^{1}$, Cumhur Türk ${ }^{1}$, Erol Taş ${ }^{2}$ \\ ${ }^{1}$ Science Education Program, Faculty of Education, Ondokuz Mayıs University, Samsun, Turkey \\ ${ }^{2}$ Science Education Program, Faculty of Education, Ordu University, Ordu, Turkey \\ Correspondence: Nilay Şener, Science Education Program, Faculty of Education, Ondokuz Mayıs University, Samsun, \\ 55200, Turkey
}

Received: April 17, 2015 Accepted: May 5, 2015 Online Published: May 8, 2015

doi:10.11114/jets.v3i4.771 URL: http://dx.doi.org/10.11114/jets.v3i4.771

\begin{abstract}
The purpose of this study is to examine the effects of a science education project implemented in different learning environments on secondary school students' creative thinking skills and their attitudes to science lesson. Within this scope, a total of 50 students who participated in the nature education project in Samsun City in 2014 make up the sample of the study. For this purpose, within the scope of a five-day long project, the students were presented with hands on activities, laboratory practices, outdoor practices, creative drama, planetarium and observatory activities to enable them to view science and nature from different views. The study was designed as one group, pre-test post-test experimental research. Attitudes scale towards Science lesson and Torrance Creative Thinking Test Verbal A-B forms were used as pre-test and post-test. In addition, open-ended interview form was used in order to find out the students' views on the project. For the analysis of quantitative data, non-parametric tests Wilcoxon signed ranks test and Mann Whitney-U test were used while a parametric test, $t$-test for dependent and independent samples was used for creative thinking test scores. For qualitative data analysis, content analysis method was used. The results of the study showed that the project was effective in increasing the students' attitudes towards the subject of science and their levels of creative thinking; at the same time it was found that using different learning environments attracted the students' interests on learning science and affected them positively towards science.
\end{abstract}

Keywords: science project, different learning environment, creative thinking, attitude

\section{Introduction}

Science has become an indispensable part of our daily lives by manifesting itself in every field of our lives. From very young ages, human beings are inherently curious and they try to find solutions to their problems by research. They try to understand and explain the phenomena around them and the universe they live in. From their childhood onwards, they try to understand the world they live in by asking questions such as "what happened?", "how did it happen?" in the events they encounter in their daily lives.

Children ask questions to people around them and they present characteristics of researchers by thinking like young scientists. It is the duty of teachers and scientists to enable keeping alive these feelings of curiosity in children (Allen, 1991). Thus, it will be of use to prepare activities that increase children's interest and motivation towards science, activities that they can relate with their daily lives and activities that can enable them to form learning experiences they can transfer to new situations. By showing sample activities to children from different areas of science, we should make them feel that they are a part of nature and they need science to understand nature. Science and nature studies are important since they help children's development, affect their behaviors, develop their interests, teach them more effective ways of thinking and improve their problem solving skills (SVET, 2007). Nature education activities help students to interact directly with nature and to perceive different aspects of the natural world (Palmerg \& Kuru, 2000).

As is known, children learn best when they are responsible of their own learning and when they are actively involved in the learning process. Prominent writers such as Piaget, Ausubel and Wallot have emphasized that students should be an active part of learning (Driver, Guesne, \& Tiberghien, 1998). Because science deals with and examines real life events, students need experiences that they can actively take part in (Sağırlı \& Gürdal, 2002). Thus, a science education program rich in teaching methods and techniques that students actively participate in, enabling platforms for discussion and 
leading students to think and produce will be effective in learning.

\subsection{Science Education Project as Alternative Learning Environment}

With the beginning of the $21^{\text {st }}$ century, many teaching practices developed in alternative schools, such as student-centered and independent learning, project-based and cooperative learning, as well as authentic assessment seem to have gone main stream by influencing the culture of public education. Camps and non-formal nature activities contribute to an increase in students' emotional tendencies (Crompton \& Sellar, 1981).

When literature is reviewed in terms of such projects of science teaching, it can be seen that a great number of studies were effective on students' cognitive and affective learning. In their project they conducted on the reflections of science to nature with various science and nature activities, Balım et al. (2013) included activities that students actively participated in and that enabled students to think and question. At the end of the project, it was concluded that project activities were effective in increasing secondary school students' scientific process skills. In the ecology based summer nature education program by Erdoğan (2011), positive contributions were made to the responsible behaviors of the students who participated in the study. At the end of their five day long non-formal summer school on biological diversity, Mittelstaedt, Sanker and Vanderveer (1999) found that students developed positive attitudes towards the environment. In their project about astronomy teaching through models, Kalkan et al. (2014) enabled secondary students in ten different cities of Turkey which are at the same longitude to realize the method of measuring the circumference of the Earth that was done by Eratosthenes in 276 B.C. in the cities of Alexandria and Syene by measuring the shadow lengths of sunrays.

A science education project was planned by starting from the results of the above mentioned scientific researches on science teaching. The project was found to be worthy of support by The Scientific and Technological Research Council of Turkey, the highest institution that supports scientific and technological researches in Turkey. The project is named as "Mobile Science School" (MSS) and its theme is built on "Training Young Scientists". In this project, teaching methods with which students can actively learn by themselves within the learning process are included. With this purpose, various implementations such as hands-on learning experience, model developing, laboratory activities, outdoor activities, creative drama, planetarium and observatory were used within the project and thus the students were made to actively take part in the learning process. In addition, another purpose of this study was to increase the interest and creativity of secondary school students living in rural areas with low economic levels and difficult transportation in the subjects of science and nature and to show them what they can do in the future in terms of science.

\subsection{The Design of MSS Project}

In the implementation design used in the project, learning environments such as planetarium, observatory and laboratory in which students can actively participate within the process of learning and various teaching methods such as hands-on, experimental method, field trip, observation and creative drama were brought together and blended (Figure 1).

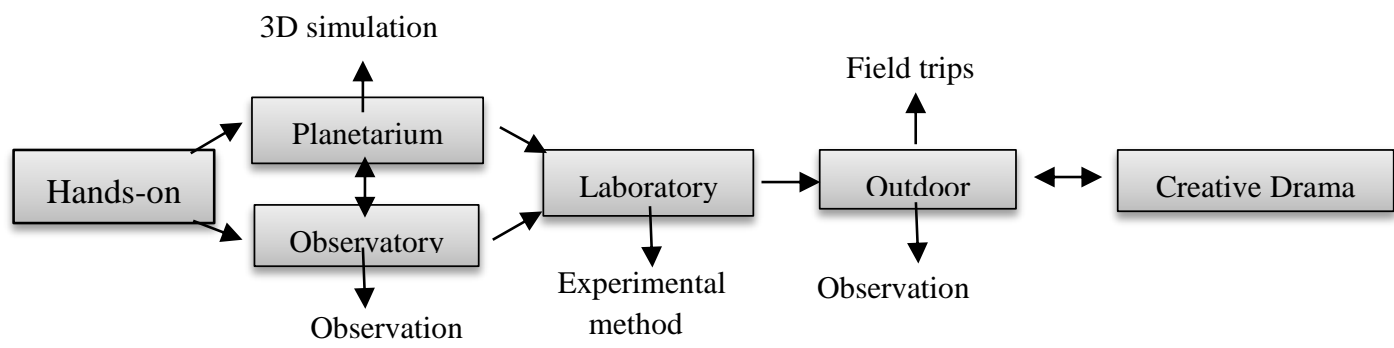

Figure 1. Implementation design of MSS project

Hands-on learning concept can be defined as the use of concrete materials in activities both inside and outside the classroom. In addition, hands-on learning experience should not be considered only as the manipulation of materials or variables used during activities. Hands-on learning is making thorough researches with objects, materials, phenomenon and ideas and to get a meaning and understanding from these experiences. This learning experience includes both mental and physical learning. Studies have shown that teaching with models is effective in learning (Stocklmayer, 2010); hands-on activities increase the positive attitude and motivation towards science lessons and making models and using these models increases students' success (Sarıkaya, Selvi \& Bora, 2004). A hand on workshop means students' developing their own learning materials. Thanks to the materials they develop, students both learn to use different materials and develop their imagination and self-confidence. In addition, since the materials are presented for the use of all students, this enables them to develop the spirit to share. 
Laboratory experiments enable students to gain conceptual information and to develop skills such as solving problems, collecting data, planning and conducting a research, analyzing the data and making conclusions. Laboratory works make important contributions for the students to form their own knowledge and psychomotor skills by understanding the nature of science (Garnett \& Garnett, 1995; Singer, Hilton \& Schweingruber, 2005). By using laboratory in science education, students develop positive attitudes to science (Freedman, 1997). Science learned through experiments arouses students' natural motives and enable them to persist in learning science (Kaptan, 1998). At the same time, it teaches children to ask questions, to learn through research, to define problems and to look for an answer by working in cooperation with others (Turkish Higher Education Council, 1997).

Planetariums simulate in 3D the skyscape in any time and any place of the Earth and they enable some cycles to be understood better through its feature of going backward and forward in time. In addition, planetariums help people to experience things that they cannot experience in class, on TV and in front of the computer due to their makeup that involves the viewers. Visual and interior technology merges in planetariums. This situation facilitates the presentation and teaching of scientific concepts which are difficult to present through other media (Türk \& Kalkan, 2015). Planetariums and observatories should not be thought separately from schools or educational institutions. These are places which provide formal and informal learning. According to Hannu (1993), activities outside formal teaching sources make learning more effective and more fun. These activities are mainly activities that are realized in informal learning situations (science centers, planetariums, observatories, museums, zoos, botanic parks, woodlands, libraries, aquariums, nature centers, etc.)

Outdoor activities show students the association between different disciplines and help the students who participate in these activities to understand the subjects in these teaching programs better. Thus, students are able to correlate between subjects better (Heather, 1999). Teaching in out-of-classroom environments requires that the learners be involved in experiencing. In this way, students are motivated to use all of their senses (multisensory learning) in seeking answers to the countless mysteries that confront them every step along the outdoor path to inquiry (Hammerman D., Hammerman M. \& Hammerman E., 2001). Nature education in general means making sense of the nature as a whole. In addition, nature education enables individuals to develop awareness, knowledge, understanding and attitude towards nature and problems of nature and contribute to their developing attitudes for environmental values (Erdoğan \& Özsoy, 2007).

Field trips enable students to get firsthand experience on a subject, to develop their creative thinking and to gain the skills to associate between the real world they live in and the school (Kalaycı \& Büyükalan, 2000). Field trips within nature educations and the activities in these trips present the real life equivalent of knowledge (Erentay \& Erdoğan, 2006). Creative drama is the actions and improvisation of the participants through their own creative discoveries, authentic thoughts, subjective memories and knowledge without a pre-written text (San, 1990). It aims to make learning by doing and experiencing more lasting, to make subjects easier, to concretize abstract concepts and to provide an effective and meaningful learning (Hatipoğlu, 2006). Group works during creative drama workshops in science lessons provide social development and increase communication (Bentley \& Watts, 1989).

\subsection{The Purpose of Research}

The purpose of this research is to examine the effects of MSS project on the attitudes of secondary school students towards science lesson and their creative thinking skills. Thus, the research tries to answer the following question.

"How is the change in the attitudes of secondary school students who participated in MSS project towards science lesson and their levels of creative thinking skill?"

Besides, the project also seeks to determine the general views and recommendations of students in terms of the project process.

Starting from the research problem, answers were sought for the following sub-problems:

1. What kind of a change was observed in the pre- and post-project attitudes of the students for the science lessons?

2. Is there a significant difference between the attitudes of female and male students towards science lessons?

3. What kind of a change was observed in the pre- and post-project creative thinking levels of the students?

4. Is there a significant difference between the creative thinking levels of female and male students?

5. What are the general views and recommendations of the students in terms of the project process?

\section{The Method}

This research was designed as one-group pretest-posttest experimental research. In this research design, a single group is measured or observed not only after being exposed to a treatment of some sort but also before (Fraenkel, Wallen \& 
Hyun, 2012). Since the research was conducted with the students who participated in the five-day long MSS project, there is no control group in the research.

\subsection{The Sample}

The sample of the research consists of a total of 50 seventh graders who voluntarily participated in the MSS project which was organized in the city of Samsun in the Black Sea Region of Turkey and which was also supported by The Scientific and Technological Research Council of Turkey (Table 1). The research used convenience sampling method which is one of the nonrandom sampling methods. A convenience sample is a group of individuals who are available for study (Fraenkel, Wallen \& Hyun, 2012). Care was taken to choose the sample from students who lived in low economic level rural places difficult to reach.

Table 1. Demographic features of the participant students

\begin{tabular}{lccc}
\hline \multirow{2}{*}{ Districts } & \multicolumn{3}{c}{ Gender } \\
\cline { 2 - 4 } & Female & Male & Total \\
\hline Asarc1k & 6 & 5 & 11 \\
Canik & 4 & 7 & 11 \\
Atakum & 5 & 5 & 10 \\
Yakakent & 5 & 3 & 8 \\
Salipazar & 5 & 5 & 10 \\
Total & 25 & 25 & 50 \\
\hline
\end{tabular}

Care was taken to choose the students from six different rural areas of the city. 25 of the participants were female while 25 were male.

\subsection{The Implementation of MSS Project}

MSS project was based on six modules with different teaching methods and environments. These modules are hands-on, laboratory, planetarium, observatory, outdoor and creative drama implementations. While hands-on, outdoor, laboratory and creative drama implementations each took place in one day, planetarium and observatory implementations took place within the same day and one day was allocated to both in the program. The reason for this was that planetarium and observatory were in the same area (Ondokuz May1s University Astronomy Center). The main subjects areas covered in the project design are some basic astronomy, physics and biology concepts (Table 2).

Table 2. The subjects and activities in MSS project

\begin{tabular}{|c|c|c|c|c|}
\hline Days & Module & Learning Environment & Method & Subject \\
\hline $1^{\mathrm{st}}$ & (1) Hands-on Implementation & Workshop classroom & $\begin{array}{l}\text { Hands on } \\
\text { learning }\end{array}$ & $\begin{array}{l}\text { Simple electric motor } \\
\text { Making Galilescope } \\
\text { Solar and Lunar eclipse } \\
\text { Formation of seasons } \\
\text { Phases of Moon } \\
\text { The Constellations } \\
\text { Big-bang }\end{array}$ \\
\hline \multirow[t]{2}{*}{$2^{\text {nd }}$} & (2) Planetarium Implementation & Planetarium & 3D simulation & $\begin{array}{l}\text { Finding direction in the sky } \\
\text { Constellations } \\
\text { Latitude and longitudes }\end{array}$ \\
\hline & (3) Observatory Implementation & Observatory & Observation & $\begin{array}{l}\text { Observing the Sun, Moon and } \\
\text { Planets }\end{array}$ \\
\hline $3^{\text {rd }}$ & (4) Laboratory Implementation & Laboratory & $\begin{array}{l}\text { Experimental } \\
\text { method }\end{array}$ & $\begin{array}{l}\text { Using microscope } \\
\text { Examination of plant and animal } \\
\text { cells. } \\
\text { Examination of animal organs } \\
\text { Determination of blood groups } \\
\text { A simple electrical circuit }\end{array}$ \\
\hline $4^{\text {th }}$ & (5) Outdoor Implementation & $\begin{array}{l}\text { The Delta of Bafra } \\
\text { Kizilırmak }\end{array}$ & $\begin{array}{l}\text { Field trips } \\
\text { Observation } \\
\text { Creative drama }\end{array}$ & $\begin{array}{l}\text { Bird species } \\
\text { Extinct animals }\end{array}$ \\
\hline $5^{\text {th }}$ & (6) Creative Drama Implementation & Drama Classroom & Creative drama & Identification of scientists \\
\hline
\end{tabular}

While determining the science activities within the project, the purpose was to increase the students' interests in science rather than informing them. Thus, care was taken to choose the activities from simple subjects of science that students found difficult to understand but they were sure to encounter in their daily lives.

\subsection{The Data Collecting Instruments}

Quantitative and qualitative data collecting instruments were used together in accordance with the purposes of the research. For quantitative measuring instruments, attitude scale for science lesson was used while Torrance Test of 
Creative Thinking (TTCT) Verbal A-B Forms and student feedback form to get feedbacks about the project was used as qualitative data collecting instrument.

3 points Likert Scale developed by Nuhoğlu (2008) for secondary school students was used as the attitude towards science lesson scale. The Likert scale ranged from: agree (3), neutral (2), disagree (1). The scale consisted of 20 items (10 positive - 10 negative) and Cronbach-Alpha internal consistency coefficient was 0,87 . Sample items from attitudes towards science lesson scale are given in Table 3.

Table 3. Sample items of attitudes towards science lesson scale

\begin{tabular}{|c|c|c|c|}
\hline & Agree & Neutral & Disagree \\
\hline 1. & $\begin{array}{l}\text { I like trying to understand the phenomena around me by using the } \\
\text { information I learn in science and technology lesson. }\end{array}$ & & \\
\hline 4. & $\begin{array}{l}\text { Learning interesting information in Science and technology lesson arouses } \\
\text { interest in me. }\end{array}$ & & \\
\hline 13. & I have difficulty in learning the subjects in Science and technology lesson & & \\
\hline
\end{tabular}

TTCT verbal A and B developed by Torrance (1966) and adapted into Turkish by Aslan (2001) was used to determine the students' levels of creative thinking. While A form was used as pre-test before the project, B form was used as post-test after the project. Verbal test forms consist of seven subtests called "asking questions", "guessing causes", "guessing consequences", "product improvement", "unusual uses", "unusual questions" and "just suppose". The answers of the students for each test were scored in three aspects as "fluency", "abstractness" and "originality", they were added up and creative thinking score was formed. Sample question for "TTCT verbal B" is given Table 4.

Table 4. Sample question for TTCT verbal B

\begin{abstract}
Just suppose...
Now you will be given an improbable event. An event that will perhaps never come true. You will just suppose that this happens. This will give you the opportunity to think about other exciting things and use your imagination. Of course, if this improbable event comes true... just imagine that it happens. Then think about the other things that might happen with the occurrence of this event. In other words, what might the consequences of this event be? Make as many guesses as you can. That is the impossible event: Just suppose that a big fog came to the Earth and only people's feet can be seen. How is this going to change the world? List your thoughts and guesses.
\end{abstract}

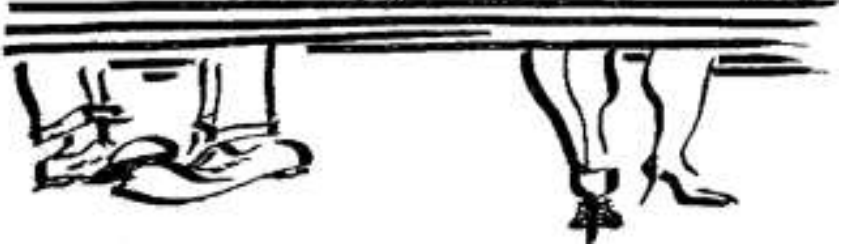

\title{
2.4 Data Analyses
}

The statistical analysis of the data obtained from the research was made with SPSS 22.0 package program. After this, Kolmogorov-Smirnov test was used to see whether the data distribution was normal before the difference between arithmetic means was tested. The $\mathrm{p}$ value calculated with Kolmogorov-Smirnov test being smaller than $\mathrm{p}<.05$ shows that at this level of significance, scores show a significant deviation from the normal distribution (Büyüköztürk, 2013). Since the data obtained from attitudes towards science scale did not show normal distribution $(\mathrm{p}<.05)$, while non-parametric Mann Whitney U test was used for independent samples, Wilcoxon Signed Ranks Test was used for dependent samples.

In the analysis of scores from TTCT Verbal A-B Forms, scoring guide formed for "fluency", "abstractness" and "originality" categories was used for the qualitative analysis of the data. The criteria to be followed while scoring the data from TCTT were formed according to the Turkish scoring guide prepared by Aslan (2001). Scorings of each category in the guide were made and the data was transformed into qualitative data. Since the scores showed normal distribution according to the Kolmogorov Smirnov test results in the analysis of total scores obtained from TTCT Verbal A-B Forms ( $p>05$ ), the data analysis was made by using dependent samples t-test and independent samples t-test. For the reliability of data analysis, a total of 16 test forms chosen randomly from TTCT Verbal A (8) and B (8). Forms were coded and scored once more by the researcher 2 months after the analysis. Consistent codes were remarked as "agreement" while inconsistent ones were remarked as "disagreement". By using the reliability formula stated by Miles and Huberman (1994), the agreement between the two scorings was calculated as $85 \%$. According to Yildirım and Şimşek (2011), coding can be said to be reliable when the agreement rate on the data is $70 \%$.

The answers in the interview form which was used to gather the student views on the project in general were analyzed through descriptive analysis. Student feedbacks obtained after the analysis were presented in tables. 


\section{Findings}

\subsection{Students' Attitudes}

Table 5 presents the pre-, post-test mean and standard deviation values of students who participated in MSS project towards science lesson.

Table 5. Mean and standard deviation values of pre-, post-test scores from attitudes towards science lesson scale

\begin{tabular}{llcc}
\hline & $\mathrm{N}$ & Mean & Std. Deviation \\
\hline Pre-test & 50 & 51,10 & 9,346 \\
Post-test & 50 & 57,05 & 3,863 \\
\hline
\end{tabular}

A difference was observed in favor of post-test between the students' pre-test pre-implementation attitudes towards science lesson $\left[\mathrm{X}_{\mathrm{Pre}}=51,10\right]$ and their post-test post-implementation attitude scores $\left[\mathrm{X}_{\text {Post }}=57,05\right]$.

Wilcoxon Signed ranks test was conducted to examine whether attitude towards science pre-, post test scores showed a significant difference (Table 6).

Table 6. Wilcoxon Signed Ranks test results of the students' pre and post project attitudes towards science lesson scale scores

\begin{tabular}{lccccc}
\hline Post test - Pre test & $\mathrm{N}$ & Mean Rank & Sum of Ranks & $\mathrm{z}$ & $\mathrm{p}$ \\
\hline Negative Ranks & $7^{\mathrm{a}}$ & 15,07 & 105,50 & $-4,330^{\mathrm{d}}$ & $\mathbf{0 , 0 0}$ \\
Pozitive Ranks & $35^{\mathrm{b}}$ & 22,79 & 797,50 & & \\
Ties & $8^{\mathrm{c}}$ & - & - & & \\
Total & 50 & - & - & & \\
\hline
\end{tabular}

${ }^{\text {a }}$ Post-test $<$ Pre-test

${ }^{\mathrm{b}}$ Post-test $>$ Pre-test

${ }^{\mathrm{c}}$ Post-test $=$ Pre-test

${ }^{\mathrm{d}}$ Based on negative ranks.

" $\mathrm{p}<0,05$

When Table 6 is examined, a significant difference is seen between pre- and post-project attitude test scores of the students who participated in the study $[\mathrm{z}=-4,330, \mathrm{p}<0,05]$. When the students' mean ranks and sum of ranks are taken into consideration, this difference can be seen to be in favor of positive ranks, that is post-test score. According to these findings, it can be said that the science project implemented has a positive effect on the students' attitudes towards science.

Attitude towards science lesson scores of the students who participated in the project were examined in terms of the gender variable and mean and standard deviation values of pre-, post-test scores of male and female students were presented in Table 7.

Table 7. Mean and standard deviation values of pre-, post-test scores of female and male students from attitudes towards science lesson scale

\begin{tabular}{cllcc}
\hline Group & & N & Mean & Std. Deviation \\
\hline \multirow{2}{*}{ Female } & Pre-test & 25 & 51,88 & 9,995 \\
& Post-test & 25 & 57,44 & 2,935 \\
Male & Pre-test & 25 & 50,32 & 8,785 \\
& Post-test & 25 & 56,66 & 4,641 \\
\hline
\end{tabular}

As can be seen from Table 7, science lesson attitude scale scores of male and female students before the project $\left[X_{F}=51,88 ; X_{M}=50,32\right]$ and after the project $\left[X_{F}=57,44 ; X_{M}=56,66\right]$ were approximately close.

Mann Whitney U-test was conducted to examine whether the students' pre- and post-test attitudes towards science differed significantly in terms of gender and the findings of the test were given in Table 8.

Table 8. Pre-test and post-test Mann Whitney U test results of science attitude scale based on gender

\begin{tabular}{lllccccc}
\hline & Group & $\mathrm{N}$ & Mean Rank & Sum of Ranks & $\mathrm{U}$ & $\mathrm{z}$ & $\mathrm{p}$ \\
\hline \multirow{2}{*}{ Pre-test } & Female & 25 & 27,96 & 699,00 & 251,00 & $-1,198$ & 0,231 \\
& Male & 25 & 23,04 & 576,00 & & & \\
\multirow{2}{*}{ Post-test } & Female & 25 & 25,80 & 645,00 & 305,00 & $-0,149$ & 0,881 \\
& Male & 25 & 25,20 & 630,00 & & & \\
\hline
\end{tabular}

${ }^{*} \mathrm{p}<0,05$

When Table 8 was examined, no significant difference was found between pre- $[U=251,00, p>0,05]$ and post-test $[\mathrm{U}=305,00, \mathrm{p}>0,05]$ male and female students' scores of attitudes towards science scale. This finding shows that 
students' pre- and post-test attitude scores did not differ in terms of gender.

In order to examine the effects of the project on female and male students' attitude scores, female and male students' pre- and post-test science lesson attitude scores were analyzed separately by using Wilcoxon signed ranks test and the results were given in Table 9.

Table 9. Pre-test and post-test Wilcoxon Signed Ranks test results of female and male students' scores from attitudes towards science scale

\begin{tabular}{|c|c|c|c|c|c|c|c|}
\hline & Post-test & Pre-test & $\mathrm{N}$ & Mean Rank & Sum of Ranks & $\mathrm{Z}$ & $\mathrm{p}$ \\
\hline & & Negative Ranks & $5^{a}$ & 7,80 & 39,00 & $-2,256^{\mathrm{d}}$ & $0,02^{*}$ \\
\hline & Female & Positive Ranks & $14^{\mathrm{b}}$ & 10,79 & 151,00 & & \\
\hline & remale & Ties & $6^{c}$ & - & - & & \\
\hline & & Total & 25 & - & - & & \\
\hline & & Negative Ranks & $2^{\mathrm{a}}$ & 6,00 & 12,00 & $-3,838^{\mathrm{d}}$ & $0,00^{*}$ \\
\hline & & Positive Ranks & $21^{\mathrm{b}}$ & 12,57 & 264,00 & & \\
\hline & Male & Ties & $2^{c}$ & & & & \\
\hline & & Total & 25 & & & & \\
\hline${ }^{a}$ Post-test $<$ Pre-test & & & & & & & \\
\hline${ }^{\mathrm{b}}$ Post-test $>$ Pre-test & & & & & & & \\
\hline${ }^{\mathrm{c}}$ Post-test $=$ Pre-test & & & & & & & \\
\hline Based on negative & ks. & & & & & & \\
\hline $\mathrm{p}<<0,05$ & & & & & & & \\
\hline
\end{tabular}

Wilcoxon signed ranks test analysis results in Table 9 show a significant difference between the pre- and post-test attitudes towards science scores of female students $[\mathrm{z}=-2,256, \mathrm{p}<0,05]$ and male students $[\mathrm{z}=-3,838, \mathrm{p}<0,05]$. When the mean rank and sum of ranks of the difference between female and male students' scores were taken into consideration, it can be seen that the difference is in favor of positive ranks, that is post-test scores. According to these findings, it can be said that the science education project implemented had a significant effect on female and male students' attitudes towards science.

\subsection{Students' Creative Thinking}

The difference between the pre- and post-test creative thinking levels of the students who participated in the MSS project were examined by dependent samples T-test and presented in Table 10.

Table 10. Dependent samples T-test results of the students' pre-test and post-test TTCT verbal A-B test scores

\begin{tabular}{lcccccc}
\hline & $\mathrm{N}$ & Mean & Std. Deviation & $\mathrm{df}$ & $\mathrm{t}$ & $\mathrm{p}$ \\
\hline Pre-test (Verbal A) & 50 & 69,50 & 28,173 & 49 & 5,399 & $\mathbf{0 , 0 0}$ \\
Post-test (Verbal B) & 50 & 92,94 & 30,355 & & & \\
\hline
\end{tabular}

${ }^{*} \mathrm{p}<0,05$

When Table 10 is reviewed, it can be seen that there is a significant difference in favor of post-test between the pre-test creative thinking verbal test scores $\left[X_{\mathrm{Pre}}=69,50\right]$ and post-test scores $\left[X_{\text {Post }}=92,94\right]$ of the students who participated in the project. Dependent samples T-test analysis results show a significant difference between the pre- and post-test creative thinking scores of the students who participated in the study [t(49)=5,399; $\mathrm{p}<0.05]$. When the mean of the students' TTCT scores are reviewed, it can be seen that this difference is in favor of post-test scores. According to these findings, it can be said that the project had a positive effect on the students' creative thinking levels.

When the students' TTCT verbal test A-B scores were examined in terms of the variable of gender, pre-test creative thinking verbal-A scores of female and male students $\left[X_{F}=68,20 ; X_{M}=70,80\right]$ are approximately close to those of post-test verbal-B scores $\quad\left[X_{\mathrm{F}}=94,96 ; \mathrm{X}_{\mathrm{M}}=90,92\right]$

Independent samples T-test was used to examine whether the students' pre- and post-test creative thinking scores differed significantly and the results were presented in Table 11.

Table 11. Independent samples T-test results of pre- and post-test TTCT verbal A-B scores based on gender

\begin{tabular}{llllcccc}
\hline & Group & $\mathrm{N}$ & Mean & Std. Deviation & $\mathrm{df}$ & $\mathrm{t}$ & $\mathrm{p}$ \\
\hline \multirow{2}{*}{ Pre-test (Verbal A) } & Female & 25 & 68,20 & 26,233 & 48 & $-0,323$ & 0,748 \\
& Male & 25 & 70,80 & 30,477 & & & \\
\multirow{2}{*}{ Post-test (Verbal B) } & Female & 25 & 94,96 & 29,835 & 48 & 0,467 & 0,643 \\
& Male & 25 & 90,92 & 31,346 & & & \\
\hline
\end{tabular}

"p $<0,05$

When independent samples T-test analysis results were examined, no significant difference was found between the pre- 
$[\mathrm{t}(48)=-0,323 ; \mathrm{p}>0.05]$ and post-test $[\mathrm{t}(48)=0,467 ; \mathrm{p}>0.05]$ creative thinking scores of female and male students. This finding shows that students' pre- and post-test creative thinking levels do not differ in terms of gender.

In order to examine the effects of the project on female and male students' creative thinking levels, female and male students' TTCT verbal pre- and post-test scores were analyzed separately by using dependent samples T-test (Table 12).

Table 12. Dependent samples T-test results of female and male students' pre- and post-test TTCT verbal A-B scores

\begin{tabular}{cccccccc}
\hline & & N & Mean & Std. Deviation & df & t & p \\
\hline \multirow{2}{*}{ Female } & Pre-test (Verbal A) & 25 & 68,20 & 26,233 & 24 & 4,925 & $\mathbf{0 , 0 0 *}$ \\
& Post-test (Verbal B) & 25 & 94,96 & 29,835 & & & \\
\multirow{2}{*}{ Male } & Pre-test (Verbal A) & 25 & 70,80 & 30,477 & 24 & 2,950 & $\mathbf{0 , 0 1 *}$ \\
& Post-test (Verbal B) & 25 & 90,92 & 31,346 & & & \\
\hline
\end{tabular}

${ }^{*} \mathrm{p}<0,05$

Dependent samples T-test analysis results show a significant difference between the creative thinking pre- and post-test scores of female students $[\mathrm{t}(24)=4,925 ; \mathrm{p}<0.05]$ and male students $[\mathrm{t}(24)=2,950 ; \mathrm{p}<0.05]$. When the mean scores of female and male students are taken into consideration, it can be seen that this difference is in favor of post-test scores. According to these findings, the project can be said to have an effect on the creative thinking levels of female and male students.

\subsection{Findings of Student Feedback Form}

The students were asked to give feedback on the modules of the project. The students' answers to the feedback form are given in Table 13.

Table 13. Results of the student feedback form in terms of modules

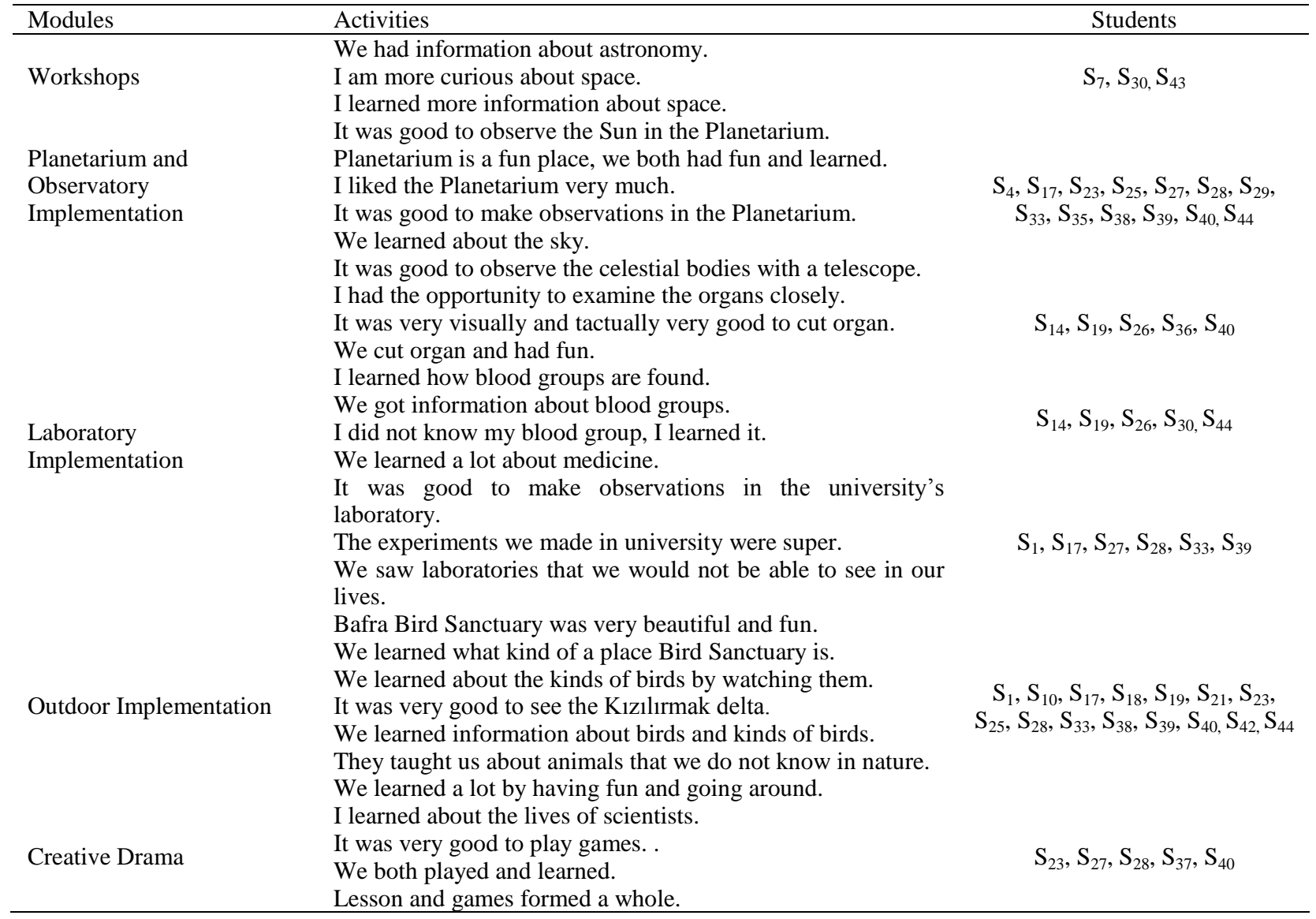

When the students' feedbacks in Table 13 are examined, what stands out is the students' expressions about both having fun and learning in different learning environments throughout the project. They specifically pointed out that making observations in teaching environments such as planetarium and observatory was fun. They also stated in workshop studies that their curiosity increased and they got information about space. They stated that learning by touching was effective in a laboratory environment and at the same time they stated that making experiments in university impressed them. 
Some recommendations for the project in general are presented in Table 14 in categories.

Table 14. Students' recommendations on the project in student feedback form

\begin{tabular}{|c|c|c|}
\hline Categories & Recommendations & Students \\
\hline Duration of the project & $\begin{array}{l}\text { The project should be longer. } \\
\text { If the project had lasted longer, it would be } \\
\text { perfect. } \\
\text { Let's make the day longer than } 5 \text { days. }\end{array}$ & $\begin{array}{c}\mathrm{S}_{9}, \mathrm{~S}_{12}, \mathrm{~S}_{13}, \mathrm{~S}_{17}, \mathrm{~S}_{19}, \mathrm{~S}_{20}, \mathrm{~S}_{26}, \mathrm{~S}_{27}, \mathrm{~S}_{28}, \mathrm{~S}_{29}, \mathrm{~S}_{34}, \\
\mathrm{~S}_{37}, \mathrm{~S}_{38}, \mathrm{~S}_{39}, \mathrm{~S}_{40}\end{array}$ \\
\hline Repetition of the project & $\begin{array}{l}\text { Let's do the same activity next year. It had } \\
\text { nothing missing. } \\
\text { We want the same project next year. } \\
\text { Let } 7 \text { th graders be brought to the project like this } \\
\text { every year. }\end{array}$ & $\begin{array}{c}\mathrm{S}_{10}, \mathrm{~S}_{25}, \mathrm{~S}_{33}, \mathrm{~S}_{36}, \mathrm{~S}_{39}, \mathrm{~S}_{40} \\
\mathrm{~S}_{2}, \mathrm{~S}_{4}\end{array}$ \\
\hline $\begin{array}{l}\text { Teaching environment and } \\
\text { activities }\end{array}$ & $\begin{array}{l}\text { The trip should be longer and more places should } \\
\text { be covered. } \\
\text { There should be more games of creativity. } \\
\text { Let's watch the birds closer in Bird Sanctuary. }\end{array}$ & $\mathrm{S}_{15}, \mathrm{~S}_{16}, \mathrm{~S}_{10}$ \\
\hline
\end{tabular}

When Table 14 is examined, it can be seen that students made recommendations on the duration of the project, repetition of the project and on teaching environment and activities. They stated that they wanted the project to be longer, they wanted more field trips and the project to be repeated.

\section{Conclusion}

The purpose of the science education project was to develop different teaching environments that can increase the students' curiosity and willingness to learn and to enable the students to realize simple scientific phenomena and scientific events around them. With this purpose, within a five day long project, the students were presented with scientific and nature activities including hands-on, laboratory, outdoor, creative drama, planetarium and observatory activities that can enable them to view science and nature from different views.

There are a great number of researches which suggest that students' cognitive and affective skills improve in learning environments which use models that enable the subjects in science lessons to be associated with daily life and in which students learn by forming their own models (Gilbert, 2004; Sarıkaya, Selvi \& Bora, 2004; Gümüş, Demir, Koçak, Kaya $\&$ Kırıc1, 2008) There are also a great number of studies which suggest that science teaching through experiments is effective in learning and that planetarium and outdoor implementations make it much easier for students to understand science subjects (Freedman, 1997; Heather, 1999; Türk \& Kalkan, 2015). Activities such as hands-on, observatory experiments, creative drama, modeling activities, field trips were used within the project and as a result of these activities, the students were able to learn by themselves, comprehend the subjects more easily by making them more concrete, show positive attitudes towards science and develop their creative thinking. The study which used different teaching environments and methods was reported to attract the students' interests in learning science and to affect them positively.

In teaching environments, socioeconomic conditions play an important role in realizing and determining teaching activities (Koosimile, 2004). Students in this study were chosen especially from areas with low economic levels and areas which are difficult to get to. Thus, throughout the project, it was possible to improve the perspectives and attitudes of students from rural areas towards the teaching of science.

At the end of the study, it was presented that MSS project was effective in increasing the female and male students' attitudes towards science lesson and their creative thinking skills. This result shows that the project was effective in improving the attitude and creative thinking of both female and male students

When the students' feedbacks are reviewed, it can be seen that students stated both having fun and learning through different teaching environments during the project. They also stated that in teaching environments such as planetarium and observatory, it was fun to observe, hands-on activities increased curiosity; learning by touching in laboratory was effective and at the same time, making experiments in the university affected them.

\subsection{Research Limitations and Future Directions}

-Nature education projects in the field of science education will help individuals to develop positive views and contribute to their upbringing as a creative individual who can see the events from different views.

-In future studies, experimental designs with control group can be implemented to test the effect of science education projects on learning outputs more effectively. Thus, different teaching environments and teaching methods can be compared and the efficacy of science education projects in education can be tested.

-Increasing the number of such education projects can help the students to avoid prejudices about learning science, to understand that science is a part of everyday life and to understand that science means to understand the 
universe. At the same time, longer projects and more field activities can present more effective results in the students' cognitive and affective learning. It is thought that this project will be a model for science projects in the field of science teaching through integrating different teaching environments and different teaching methods.

\section{Acknowledgments}

This work was funded by TUBITAK (The Scientific and Technological Research Council of Turkey), Project No. 213B705.

\section{References}

Allen, D. (1991). Hands on science. New York: The Center for Applied Research in Education.

Aslan, E. (2001). Torrance yaratıcı düşünce testi’nin türkçe versiyonu. Mustafa Kemal Üniversitesi Atatürk Eğitim Fakültesi Eğitim Bilimleri Dergisi, 14, 19-40.

Balım, A. G., Çeliker, H. D., Türkoğuz, S., \& Kaçar, S. (2013). The effect of reflections of science on nature project on students' science process skills. Journal of Research in Education and Teaching, 2(1), 149-157.

Bentley, D., \& Watts, M. (1989). Learning and teaching in school science. Milton Keynes: Open University Press.

Büyüköztürk, Ş. (2013). Data analysis for social sciences handbook (18th edition). Ankara: Pegem Academy.

Crompton, J. L., \& Sellar, C. (1981). Do outdoor education experiences contribute to positive development in the affective domain? The Journal of Environmental Education, 12(4), 21-29. http://dx.doi.org/10.1080/00958964.1981.9942638

Driver, R., Guesne, E., \& Tiberghien, A. (1998). Children's ideas and the learning of science, children's ideas science. Buckingham, Great Britain: Open University Press, 10, 1-9.

Erdoğan, M. (2011). The Effects of ecology-based summer nature education program on primary school students' environmental knowledge, environmental affect and responsible environmental behavior. Educational Sciences: Theory \& Practice, 11(4), 2223-2237.

Erdoğan, M., \& Özsoy, A. M. (2007). Graduate students' perspectives on the human and environment relationship. Journal of Turkish Science Education, 4(2), 21-30.

Erentay, N., \& Erdoğan, M. (2006). Initial findings of 'UNIQUE and UNIVERSAL' Project. M. F. Costa, \& B. V. Dorrio (Eds.). Science education and sustainable development (pp. 390398). University of Minho, Braga, Portugal; the Hands on Science Network.

Fraenkel, J. R., Wallen, N. E., \& Hyun, H. H. (2012). How to Design and Evaluate Research in Education. (Eight Edition). New York: Mc Graw Hill.

Freedman, P. M. (1997). Relationship among laboratory instruction, attitude toward science, and achievement in science knowledge. Journal of Research in Science Teaching, 34, 343-357. http://dx.doi.org/10.1002/(SICI)1098-2736(199704)34:4<343::AID-TEA5>3.0.CO;2-R

Garnett, P. J., \& Garnett, P. J. (1995). Refocusing the chemistry lab.: A case for laboratory-based investigations. Australian Science Teachers Journal, 41(2), 26-33.

Gilbert, J. K. (2004). Models and Modelling: Routes to More Authentic Science Education. International Journal of Science and Mathematics Education, 2(2), 115-130. http://dx.doi.org/10.1007/s10763-004-3186-4

Gümüş, İ., Demir, Y., Koçak, E., Kaya, Y., \& Kırıcı, M. (2008). Modelle öğretimin öğrenci başarısına etkisi. Erzincan Journal of Education, 10(1), 65-90.

Hammerman, D. R., Hammerman, W. M., \& Hammerman, E. L. (2001). Teaching in the outdoors (Fifth Edition). U.S.A: Interstate Publishers.

Hannu, S. (1993). Science centre education. Motivation and learning in informal education, Thesis (PhD), Helsinki University Department of Teacher Education, Finland.

Hatipoğlu, Y. Y. (2006). Illköğretim 5. sınıf matematik ders konularının öğretiminde drama yönteminin öğrenci başarısına etkisi. Unpublished Master Thesis, Gazi University Institute of Educational Sciences, Ankara.

Heather, P. (1999). Experiential environmental education for primary aged-children (ERIC Document Reproduction Service No. ED 471 723).

Kalaycı, N., \& Büyükalan, S. (2000). İlköğretim okullarında uygulanan gözlem gezisi yöntemine ilişkin gezi planı model önerileri. Cukurova University Faculty of Education Journal, 2(18), 137-146. 
Kalkan, H., Kıroğlu, K., Türk, C., Bolat, M., Kalkan, S., \& Aslantürk, A. (2014). Basic astronomy concepts in the footsteps of Eratosthenes. Procedia - Social and Behavioral Sciences, 116(2014), 3731-3739. http://dx.doi.org/10.1016/j.sbspro.2014.01.832

Kaptan, F. (1998). Teaching science. Istanbul: Ministry of Education Publications Teacher Books Series.

Koosimile, A. T. (2004). Out-of-school experiences in science classes: problems, issues and challenges in Botswana. International Journal of Science Education, 26(4), 483 - 496. http://dx.doi.org/10.1080/0950069032000097415

Miles, M. B., \& Huberman, A. M. (1994). Qualitative data analysis: An expande sourcebook (2nd edition). Thousand Oaks, CA: Sage.

Mittelstaedt, R., Sanker, L., \& Vanderveer, B. (1999). Impact of a week-long experiential education program on environmental attitude and awareness. Journal of Experiential Education, 22(3), 138-148. http://dx.doi.org/10.1177/105382599902200306

Nuhoğlu, H. (2008). The Development of an Attitude Scale for Science and Technology Course. Elementary Education Online, 7(3), 627-639.

Palmerg, I. E., \& Kuru, J. (2000). Outdoor activities as a basis for environmental responsibility. Journal of Environmental Education, 31(4), 32-37. http://dx.doi.org/10.1080/00958960009598649

Sağırlı, H. E., \& Gürdal, A. (2002). Impact of creative drama technique on students' attitudes in the science course, V. National Science and Mathematics Education Congress, Ankara.

San, İ. (1990). Creative drama in education. Ankara University Faculty of Educational Sciences Journal, 23(2), 573-582.

Sarıkaya, R., Selvi, M., \& Bora D., N. (2004). The importance effect of the use of models in teaching of mitosis and meiosis. Kastamonu Education Journal, 12(1), 85-88.

Singer, S., Hilton, M., \& Schweingruber, H. (2005). Needing a new approach to science labs. The Science Teacher, 72(7), 10 .

Stocklmayer, S. (2010). Teaching direct current theory using a field model. International Journal of Science Education, 32(13), 1801-1828. http://dx.doi.org/10.1080/09500690903575748

SVET (Project for Strengthening Vocational Education and Training System). (2007). Child development and education in science and nature activities module, Ankara.

Torrance, E. P. (1966) Torrance tests of creative thinking: Norms-technical manual (Research ed.). Princeton, NJ: Personnel Press.

Türk, C., \& Kalkan, H. (2015). The effect of planetariums on teaching specific astronomy concepts. Journal of Science Education and Technology, 24(1), 1-15. http://dx.doi.org/10.1007/s10956-014-9516-6

Turkish Higher Education Council. (1997). Science education in elementary. National Education Development Project, Ankara.

Yıldırım, A., \& Şimşek, H. (2011). Qualitative research methods in social sciences (8th edition). Ankara: Seçkin Publishing.

\section{$(\mathrm{cc}) \mathrm{BY}$}

This work is licensed under a Creative Commons Attribution 3.0 License. 